\title{
Non-Isothermal Pyrolysis Kinetic Studies of Kraft Pulp Mill Sludge and Its Blending with Coal Powder
}

\author{
Syamsudin ${ }^{1}$, Tobias Richards ${ }^{2}$, Herri Susanto ${ }^{3}$, Subagjo ${ }^{3}$ \\ ${ }^{1}$ Center for Pulp and Paper, Jl. Raya Dayeuhkolot No. 132, Bandung - Indonesia \\ ${ }^{2}$ School of Engineering, University of Borås, Allégatan 1, SE-501 90 Borås - Sweden \\ ${ }^{3}$ Chemical Engineering Department, Faculty of Industrial Technology \\ Institut Teknologi Bandung, Jl. Ganesha 10, Bandung - Indonesia \\ Diterima : 01 Mei 2019, Revisi akhir : 15 Juni 2019, Disetujui terbit : 30 Juni 2019

\section{Studi Kinetika Pirolisis Non-Isotermal Lumpur Industri Pulp Kraft dan Campurannya dengan Serbuk Batubara}

\begin{abstract}
Abstrak
Pirolisis non-isotermal lumpur industri pulp kraft dan campurannya dengan serbuk batubara telah diselidiki. Pencampuran lumpur dengan batubara menghasilkan peningkatan waktu untuk menyelesaikan pirolisis. Fenomena ini menunjukkan bahwa zat volatil dalam batubara lebih sulit terdegradasi. Pirolisis lumpur pada 10,15 , dan $20^{\circ} \mathrm{C} /$ menit menghasilkan fraksi massa residu masing-masing $64,6 \% \mathrm{~b} / \mathrm{b}, 62,4 \% \mathrm{~b} / \mathrm{b}$, dan $64,4 \%$ $\mathrm{b} / \mathrm{b}$. Penambahan batubara ke dalam lumpur mengurangi hasil arang. Penurunan hasil arang disebabkan oleh kandungan abu batubara yang lebih rendah dibandingkan dengan abu lumpur. Lumpur kehilangan sebagian besar massanya antara $200^{\circ} \mathrm{C}$ dan $500^{\circ} \mathrm{C}$, dan mencapai puncaknya pada $280^{\circ} \mathrm{C}$. Kehilangan massa melambat pada suhu $>500^{\circ} \mathrm{C}$. Rentang suhu yang lebar pada degradasi batubara menunjukkan bahwa batubara mengandung komponen yang memiliki suhu degradasi luas, seperti lignin. Berdasarkan kurva laju kehilangan massa, terdapat tiga puncak reaksi yang menunjukkan tiga mekanisme reaksi pirolisis lumpur-batubara. Semua puncak tersebut mengikuti mekanisme reaksi orde pertama. Puncak pertama kemungkinan terjadi karena dekomposisi hemiselulosa, dan komponen-komponen lain yang sangat mudah menguap. Puncak kedua dan ketiga masing-masing berhubungan dengan selulosa dan lignin. Sifat stabilitas termal yang tinggi menyebabkan degradasi lignin yang lambat, dan kehilangan massa terjadi dalam kisaran suhu yang sangat luas $\left(160-900^{\circ} \mathrm{C}\right)$.
\end{abstract}

Kata kunci: Pirolisis non-isotermal, lumpur industri pulp, batubara, energi aktivasi

\begin{abstract}
Non-isothermal pyrolysis of kraft pulp mill sludge and coal has been investigated. Blending sludge with coal resulted time increase to complete the pyrolysis. This phenomenon indicated that volatile matter in coal was more difficult to be degraded. Sludge pyrolysis at 10,15 , and $20^{\circ} \mathrm{C} / \mathrm{min}$ remained residual mass fraction of $64.6 \% \mathrm{w} / \mathrm{w}, 62.4 \% \mathrm{w} / \mathrm{w}$, and $64.4 \% \mathrm{w} / \mathrm{w}$, respectively. Coal addition into sludge had reduced char yield. Char yield decreasing was due to lower content of coal ash compared to sludge ash. Sludge lost most of its mass at $200^{\circ} \mathrm{C}-500^{\circ} \mathrm{C}$, reached its peak at $280^{\circ} \mathrm{C}$, and became slower at $>500^{\circ} \mathrm{C}$. Wide range of coal degradation temperature indicated that coal may contain components having a wide range temperature degradation, such as lignin. Based on the curve of mass loss rate of reaction, there were three peaks which indicates three reaction mechanisms of sludge-coal pyrolysis. All peaks followed the mechanism of first order reaction. First peak was likely to occur due to decomposition of hemicellulose and other highly volatile components. Second and third were associate with cellulose and lignin, respectively. The high thermal stability properties lead to a slow degradation of lignin, and its mass loss occurred in the a very wide of temperature range $\left(160-900^{\circ} \mathrm{C}\right)$.
\end{abstract}

Keywords: Non-isothermal pyrolysis, pulp mill sludge, coal, activation energy 


\section{Introduction}

Wastewater treatment processes of pulp mill effluent usually generates solid waste such as sludge. In a kraft pulp mill, sludge generation may be as many as 58 dried $\mathrm{kg}$ per ton of pulp (Scott, Abubakr, Smith, 1995). The sludge consists of organic and inorganic compounds, and each specific/different mill and processes has different content composition, both qualitatively and quantitatively. The organic components may come from fibers or wood residue from pulp raw material, and also from micoorganism released from activated sludge. The major constituents of wood residues are cellulose, hemicellulose and lignin, in addition to extractives, water and mineral matter. Apart from organic matter, sludge also contains inorganic materials such as wood inorganic component and chemicals from both pulping processes and wastewater treatment processes. Sodium $(\mathrm{Na})$ and sulfur $(\mathrm{S})$ are often a major sludge inorganic constituent because of the utilization of sodium hydroxide $(\mathrm{NaOH})$ and sodium sulfide $\left(\mathrm{Na}_{2} \mathrm{~S}\right)$ in the kraft processes.

Dried sludge has potential to produce a certain amount of heat due to its high content of organic substances and might considered as a potential energy resource. Utilization of sludge as an alternative energy resource may simultaneously solve the environmental and energy problem. Pyrolysis is considered as an alternative method to treat sludge, as well as to convert this kind of waste to produce energy and more valuable chemical feed stocks (Werther and Ogada, 1999). Pyrolysis is a thermal decomposition of organic compounds at elevated temperatures in an inert environment where the main products are including non-condensable gases, liquid bio-oils as well as solid char (Liu, Song, and Wu, 2015). Potential energy resources in the form offuels come from the gaseous and liquid products, whereas the solid product may be used as an adsorbent for pollutants removal of contaminated water (Coimbra et al., 2015). Pyrolysis, in addition to being an independent process for producing various chemical compounds and fuels, may also be considered as the initial stage of thermal conversion process of carbonaceous materials, including combustion and gasification (Fang et al., 2015). As the initial stage in all main thermochemical conversion routes, pyrolysis has important effects on the reaction kinetics and products distribution of the follow-up process (Chen et al., 2018).

Sludge has a high content of ash and volatile matter, but a low content of fixed carbon. The high ash content may decrease the specific calorific value of the sludge. To improve its quality as a fuel, sludge can be blended with coal. Coal has a role to increase calorific value of the sludge, and has low ash content and high calorific value. Based on these properties, a blending of sludge and coal can improve the properties of the sludge as a solid fuel. If these blended materials are processed in co-pyrolysis process, multiple synergistic interactions between sludge components and coal components may occur. This process may lead to a variation in the thermal reactivity of the blended materials and on the physical properties and chemical properties of the product generated. Recently, a number of studies have reported the co-pyrolysis characteristics of sludges (Fang et al. (2015); Coimbra et al. (2015); Xiao et al. (2015); Wang et al. (2016). Fang et al. (2015) studied thermogravimetric analysis of the co-pyrolysis of paper sludge and municipalsolidwastethroughathermogravimetric simultaneous thermal analyzer from room temperature to $1000^{\circ} \mathrm{C}$. It was reported that with the increase of paper sludge ratio, the mass loss peak was also increased. Coimbra et al. (2015) studied thermogravimetric analysis of the copyrolysis of a bituminous coal and pulp mill sludge. The paper reported that compared to coal, pyrolysis of pulp mill sludge may started at lower temperatures and involving larger devolatilization and produced smaller yield of char. Blending pulp mill sludge with coal may causes an increase in the pyrolysis reactivity and a decrease in the corresponding activation energy (E).

The number of reactions involved in pyrolysis may vary depending on the number of components contained in the blending materials. In thermogravimetry analysis (TGA), three peaks usually appear that can be assigned to pseudo components of biomass, namely cellulose, hemicellulose, and lignin. It is well known that cellulose, hemicellulose, and lignin are the building blocks of biomass material (Chen et al, 2017). Data obtained from TGA are used to determine some kinetic parameters like activation energy, pre-exponential factor, and reaction mechanism (Sharma, Pandey, and Diwan, 2019). 
Table 1. The properties of the sludge and the coal

\begin{tabular}{|c|c|c|c|}
\hline No. & Analysis & Sludge & Coal \\
\hline 1. & $\begin{array}{l}\text { Proximate }(\mathrm{db}) \text { : } \\
\text { a. Volatile } \\
\quad \text { matter } \\
\text { b. Fixed carbon } \\
\text { c. Ash }\end{array}$ & $\begin{array}{l}55.02 \% \\
11.15 \% \\
33.83 \%\end{array}$ & $\begin{array}{c}48.80 \% \\
48.44 \% \\
2.76 \%\end{array}$ \\
\hline 2. & $\begin{array}{l}\text { Ultimate }(\mathrm{db}) \text { : } \\
\text { a. Carbon } \\
\text { b. Hydrogen } \\
\text { c. Nitrogen } \\
\text { d. Total sulfur } \\
\text { e. Oxygen }\end{array}$ & $\begin{array}{c}33.03 \% \\
4.35 \% \\
2.71 \% \\
0,48 \% \\
25,60 \%\end{array}$ & $\begin{array}{c}70.64 \% \\
4.45 \% \\
0.94 \% \\
- \\
21.21 \%\end{array}$ \\
\hline 3. & $\begin{array}{l}\text { Calorific value } \\
(\mathrm{db})\end{array}$ & $13.12 \mathrm{MJ} / \mathrm{kg}$ & $24.91 \mathrm{MJ} / \mathrm{kg}$ \\
\hline
\end{tabular}

The purpose of this study was to evaluate the thermal behavior during the pyrolysis process and develop a pyrolysis kinetic model through heating rate and composition of the sludge-coal variations. A study of pyrolysis kinetics may assist us in predicting the pyrolysis behavior of the biomass and also to design efficient pyrolytic reactors for engineering applications (Zhou et al., 2015). Based on the curve of mass loss rate of pyrolysis reactions, pyrolysis kinetics of sludge and its blending with coal was determined to the temperature variation obtained with the thermogravimetric analyzer. The thermal decomposition profile of the blending of sludge and coal was evaluated in non-isothermal conditions on some variation of heating rate.

\section{Materials and Method}

\section{Materials}

The materials used in this study were sludge and coal powder. The sludge was obtained from a kraft pulp mill in South Sumatera. The sludge contained the main organic components, i.e. hemicellulose $6.15 \% \mathrm{w} / \mathrm{w}$; total cellulose $49.16 \% \mathrm{w} / \mathrm{w}$ and lignin $14.15 \% \mathrm{w} / \mathrm{w}$. In order to reduce its degradation by microorganism, the sludge was dried using a drying oven at temperature of $110^{\circ} \mathrm{C}$ for 24 hours. The dried sludge was crushed and screened to obtain a sample with particle size of 16-32 mesh. The coal powder was obtained from Thermofluid and Utilities System Laboratory, Chemical Engineering Department, ITB with particle size of 16-32 mesh. The properties of the sludge and the coal are presented in Table 1. In this experiment, the blending of sludge-coal was prepared with the composition of $0 \% \mathrm{w} / \mathrm{w}$, $20 \% \mathrm{w} / \mathrm{w}, 50 \% \mathrm{w} / \mathrm{w}$ and $100 \% \mathrm{w} / \mathrm{w}$ of coal.

\section{Equipment}

Pyrolysis experiments were carried out using thermogravimetric analyzer with a combination of the magnetic suspension balance and a gas and/or vapor dosing system (Figure 1) under $\mathrm{N}_{2}$ atmosphere. The flow rate of $\mathrm{N}_{2}$ gas was kept at $100 \mathrm{~mL} / \mathrm{min}$ to ensure an inert atmosphere. Nitrogen gas was also used as a carrier gas during pyrolysis experiments that will carry out

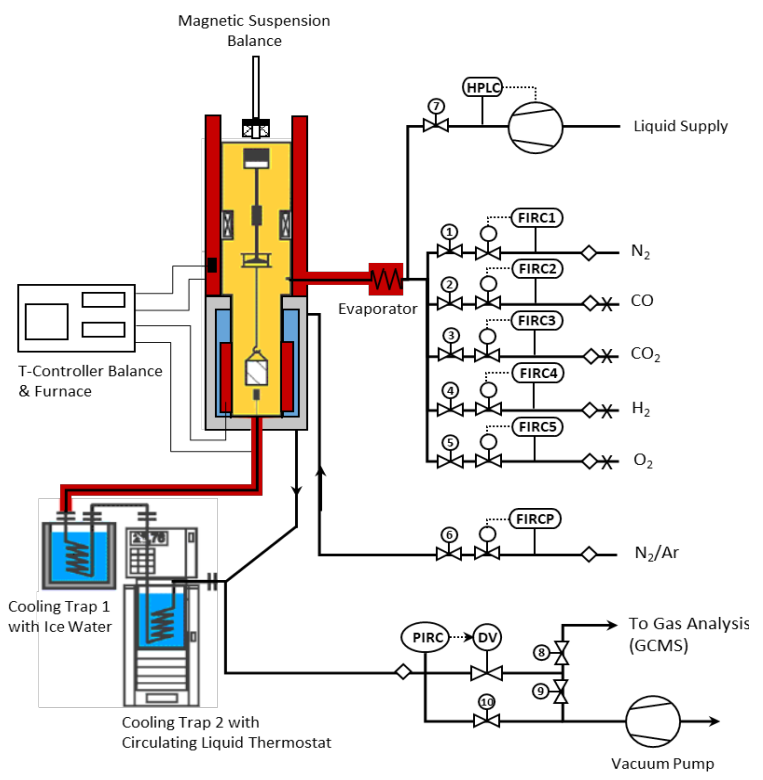

Figure 1. The non-isothermal pyrolysis experimental set-up 
the volatile gases formed immediately during pyrolysistopreventre-polymerization reaction and further decomposition. The pyrolysis was carried out non-isothermally with heating rate of 10,15 , and $20^{\circ} \mathrm{C} / \mathrm{min}$ in atmospheric pressure (1 bar). About $0.3 \mathrm{~g}$ of sample was used in every experiment. The sample was introduced into the reactor, then heated in nitrogen environment at varying heating rates to $105^{\circ} \mathrm{C}$ and held at this temperature to remove moisture. The sample was then heated at same heating rate to the final pyrolysis temperature of $900^{\circ} \mathrm{C}$ and also held at this temperature to ensure complete devolatilization. The experiment was considered to be finished when no weight loss again.

\section{Pyrolysis Kinetics Model}

The pyrolysis kinetics parameters of sludge and its blending with coal can be calculated based on the TG data. The pyrolysis reaction may be expressed with a model of the global reaction steps as follows :

$k$

Sludge $\rightarrow$ Residue + Volatile

\section{Sludge Residue + Volatile}

The reaction is considered to be irreversible for the reason that the purge gas $\left(\mathrm{N}_{2}\right)$ carried the volatile gas away as soon as it formed. In the kinetic analysis, it is generally assumed that the reaction rate can be described by two separate functions, i.e. $k(T)$ and $f(\alpha)$. The overall reaction rate can be described by the equation 1 :

$d \alpha / d t=k(T) . f(\alpha)$

with is reaction rate, is mass loss fraction, is reaction rate constant as function of temperature, $t$ is reaction time, $T$ is absolute temperature, and is reaction model. The mass loss fraction, $\alpha$, is defined by the equation 2 :

$\alpha=\left(m_{0}-m_{t}\right) /\left(m_{o}-m_{f}\right)$

with $m_{0}$ is initial mass of sample after drying at $105^{\circ} \mathrm{C}, m_{t}$ is mass of sample at any time $t$, and $m_{f}$ is mass of sample at the end of the reaction. The mass loss fraction, defined above, is based on the mass of volatile material, after drying at $105^{\circ} \mathrm{C}$. The reaction rate constant, $k$, can be described by Arrhenius equation 3:
$k(T)=A \cdot \exp (-E a / R T)$

with $A$ is pre-exponential factor, $R$ is universal gas constant $\left(8.314 \mathrm{~J} \mathrm{~mol}^{-1} \mathrm{~K}^{-1}\right), E$ is activation energy $\left(\mathrm{J} \cdot \mathrm{mol}^{-1}\right)$, and $T$ is absolute temperature $(\mathrm{K})$. In the pyrolysis process, the heating rate, $\beta$, is considered to be constant equation 4:

$\beta=d T / d t=$ constant

Equation (1) can be modified as equation 5::

$\beta \cdot d \alpha / d T=A \cdot \exp (-E a / R T) \cdot f(\alpha)$

Iso-conversional integral method is based on the shape of the temperature integral approach:

$$
g(\alpha)=\int_{0}^{\alpha} 1 / f(\alpha) d \alpha=(A / \beta) \cdot \int_{T_{o}}^{T} \exp \left(-E_{\alpha} / R T\right) d T \ldots
$$

The right-hand side of Eq. (6) has no exact analytical solution. By applying Cauchy's rule, the expression can be solved to give:

$\ln \left[\frac{g(\alpha)}{T^{2}}\right]=\ln \left[\frac{A \cdot R}{\beta \cdot E_{u}}\left(1-\frac{2 R \cdot T}{E_{\alpha}}\right)\right]-\frac{E_{u}}{R \cdot T}$

Since, $2 R T / E<<1$

$\ln \left[\frac{g(\alpha)}{T^{2}}\right]=\ln \left[\frac{A \cdot R}{\beta \cdot E_{a}}\right]-\frac{E_{a}}{R \cdot T}$

Thus, for $\alpha=$ constant, a plot of against was obtained from the thermal curves of several heating rates resulted in a straight line where its slope values can be used to evaluate the activation energy and its intercept value can be used to evaluate the value of pre-exponential factor. Function of and were depend on the conversion mechanism and mathematical model.

In this study, the gaussian fitting model was used to clarify the pyrolysis data of sludge and its blending with coal. Deconvolution is considered as an appropriate method to study the kinetics involved during the pyrolysis of biomass. The mass loss rate peaks which complex and overlapping were separated into individual peaks to allow clarification of the composition of the sludge-coal, as well as analyze the possible reaction mechanisms that occur to its components. This model assumed that lignocellulosic biomass should contain three independently reacting pseudo 
components (hemicellulose, cellulose and lignin) (Chen et al., 2017). These components were decomposed independently to form char and volatile compounds (Sharma et al., 2019). The individual peak was considered to represent one reaction mechanism of the components of the sludge and coal.

\section{Results and Discussion}

\section{The Sludge-Coal Pyrolysis Characteristics}

Thermogravimetric profiles for nonisothermal pyrolysis of sludge, coal and blend of coal-sludge are presented in Figure 2. It was observed that some amount of water was adsorbed to the particles during samples storage. A small fraction of mass loss was observed in the drying stage, indicated by a weight decrease in the temperature range of $25-105^{\circ} \mathrm{C}$. This mass loss was occured due to evaporation of water contained in the sample during the drying stage.
It was revealed that the coal samples may adsorb up to $18 \% \mathrm{w} / \mathrm{w}$ of moisture while dry sludge only absorbs $5 \% \mathrm{w} / \mathrm{w}$ of moisture during their storage. The drying stage that was carried out before the pyrolysis stage was intended to ensure the sample was free of water content so that the mass reduction during the pyrolysis process was only from the volatilization of volatile material in the sample.

Actual decomposition was occured at the pyrolysis stage. In the pyrolysis process studied, the greatestmass loss was occurred in the coalmaterial, followed by the $(50 / 50)$ blend of sludge/coal, the $(80 / 20)$ blend of sludge/coal, and the sludge as the lowest. At heating rate of $10^{\circ} \mathrm{C} / \mathrm{min}$, the yield of char was decreased with the increasing of coal portion which are: $65,63,60$, and $56 \% \mathrm{w} / \mathrm{w}$ of sludge, the (80/20) blend of sludge/coal, the $(50 / 50)$ blend of sludge/coal, and coal, respectively. The addition of coal into the sludge may reduced the yield of char at every heating rate. The decrease of char yield was suspected due to
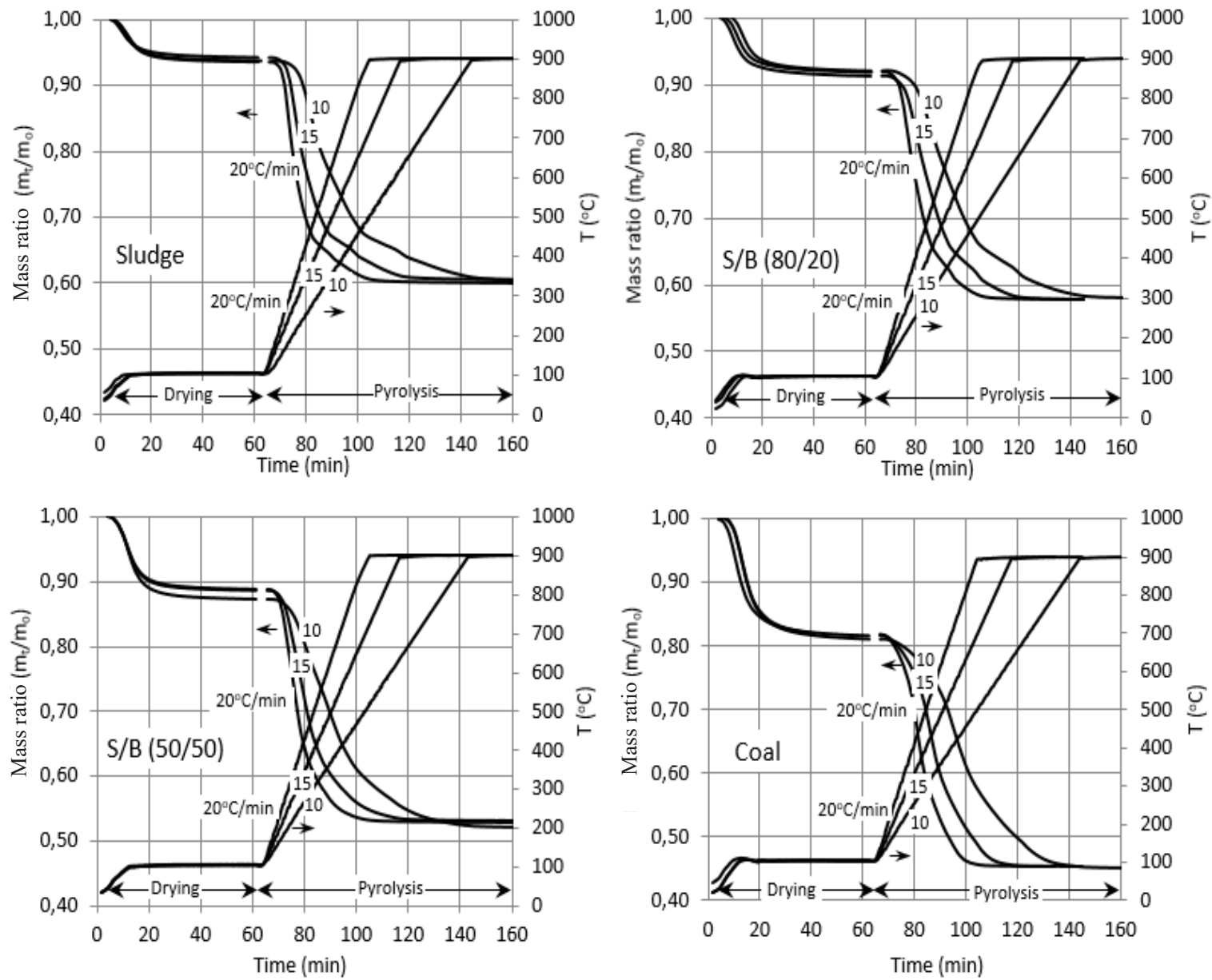

Figure 2. Sample mass loss during non-isothermal pyrolysis process 
the higher sludge ash content compared to coal. The more coal was added, the smaller ash contain in the blend of sludge-coal, therefore smaller yield of char. After being placed at $900^{\circ} \mathrm{C}$ for more than $20 \mathrm{~min}$, the rate of mass loss should approximately became zero. Thus, the variance in mass over the pyrolysis experiment indicated the total amount of volatile matter.

Generally, pyrolysis at a higher heating rate should resulted in a faster mass loss rate, and the process should be completed in a relatively short time. Heating rate effect on the rate of mass loss was clearly seen in each sample, either sludge or its sludge-coal blend. The pyrolysis process of sludge at heating rate of 10,15 and $20^{\circ} \mathrm{C} / \mathrm{min}$ were completed in 80,50 and $40 \mathrm{~min}$, respectively. Higher heating rate $\left(20^{\circ} \mathrm{C} / \mathrm{min}\right)$ may formed a steeper curve of mass loss vs time, whereas at lower heating rate $\left(10^{\circ} \mathrm{C} / \mathrm{min}\right)$ it formed a more flater curve. At higher heating rates, a lot of volatile material was released which caused rapid mass loss and low yield of char. This phenomenon was occured due to higher heating rate has more heat availability for the decomposition reactions that may release volatile matter. The more volatile matter released may lead to lower yield of char, thus addition of coal may be increased the time required to complete the pyrolysis process. This phenomenon indicates that volatile matter in the coal was more difficult to be degraded compared to sludge.

The rate of mass loss at each heating rates are presented in Figure 3. The sludge was lost most of its mass on the pyrolysis temperature between $200^{\circ} \mathrm{C}$ and $500^{\circ} \mathrm{C}$. Mass loss rate reached its peak at $280^{\circ} \mathrm{C}$, while became very slow at temperature below $500^{\circ} \mathrm{C}$. Scott et al. (2006) and Biagini et al. (2002) reported similar shape of curves for a dried sewage sludge. Scott et al. (2006) reported that digested sludge lost most of its mass between 200 and $600^{\circ} \mathrm{C}$, while undigested sludge lost most of its mass between 250 and $450^{\circ} \mathrm{C}$. Rate of mass loss was approaching zero at $\sim 600^{\circ} \mathrm{C}$. Biagini et al. (2002) attributed the mass lost below $600^{\circ} \mathrm{C}$ to the thermal degradation of organic material, and the mass lost above $600^{\circ} \mathrm{C}$ to the decomposition of inorganic material, such as calcium carbonate. In this study, proximate analysis of the sludges revealed that sludges contained a large amount of inorganic
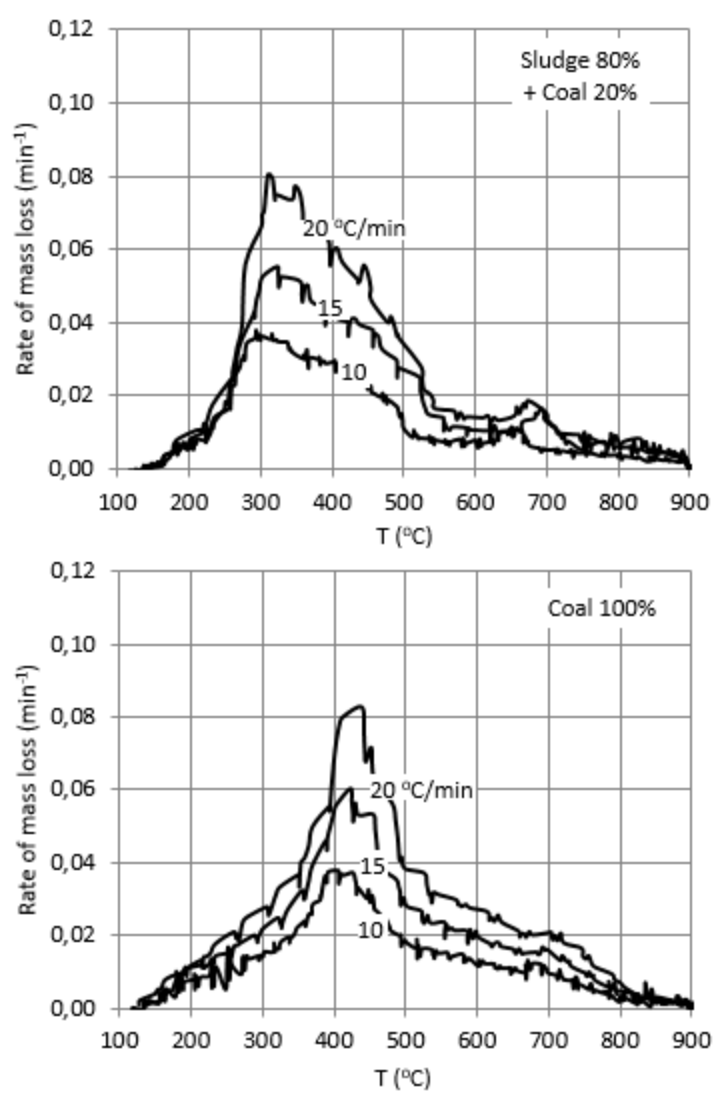

Figure 3. Mass loss fraction and mass loss rate on pyrolysis of sludge and its blending with coal 
material in the form of ash (Table 1). The coal lost most of its mass on the temperature between $200^{\circ} \mathrm{C}$ and $750^{\circ} \mathrm{C}$, with the rate of mass loss reached its peak at $430^{\circ} \mathrm{C}$. The wide temperature range of coal degradation indicates that the coal may contains some components that have wide temperature range for degradation, such as lignin. In the other hand, it may also indicates that devolatilization reactions of the coal involved more reactions than the sludge. This phenomenon could be seen from the proximate analysis of the coal which showed that the fixed carbon content was almost as high as the volatile matter content. This analysis give the indication that volatile matter in the coal may not easily degraded at low temperatures.

As seen in Figure 3, the rate of mass loss curves were gradually moved to the right side with increasing heating rate, while still maintain the shape of the curve. This may due to, at a given temperature, lower heating rate caused the sludge to take a longer time to reach the given temperature (Scott et al., 2006). The peak area was influenced by the degradation amount of volatile matter, while the peak height was influenced by the rate of mass loss. The rate of mass loss was increased with the increasing of heating rate, which indicates that there was more heat available to decompose the sludge and coal.

Several peaks can be identified on the plots of mass loss rate versus temperature in Figure 3. The peak that occurred at the low temperature was considered to be in response to degradation of hemicellulose and other highly organic volatile components, whereas the peak that occurred at the higher temperature was considered to be mainly lignin and inorganic substances. No well-defined sharp peaks can be seen in Figure 3 indicating that the devolatilization of sludge probably involves more than one reaction. The rate of mass loss peaks were appeared to be overlapping and asymmetrical, which implied that several substances in the sludge may decompose together at nearly the same temperature range (Yang and Jiang, 2009). This phenomenon can be associated with the sludge components which mostly consisted of hemicellulose, cellulose, lignin, and activated sludge microbes.
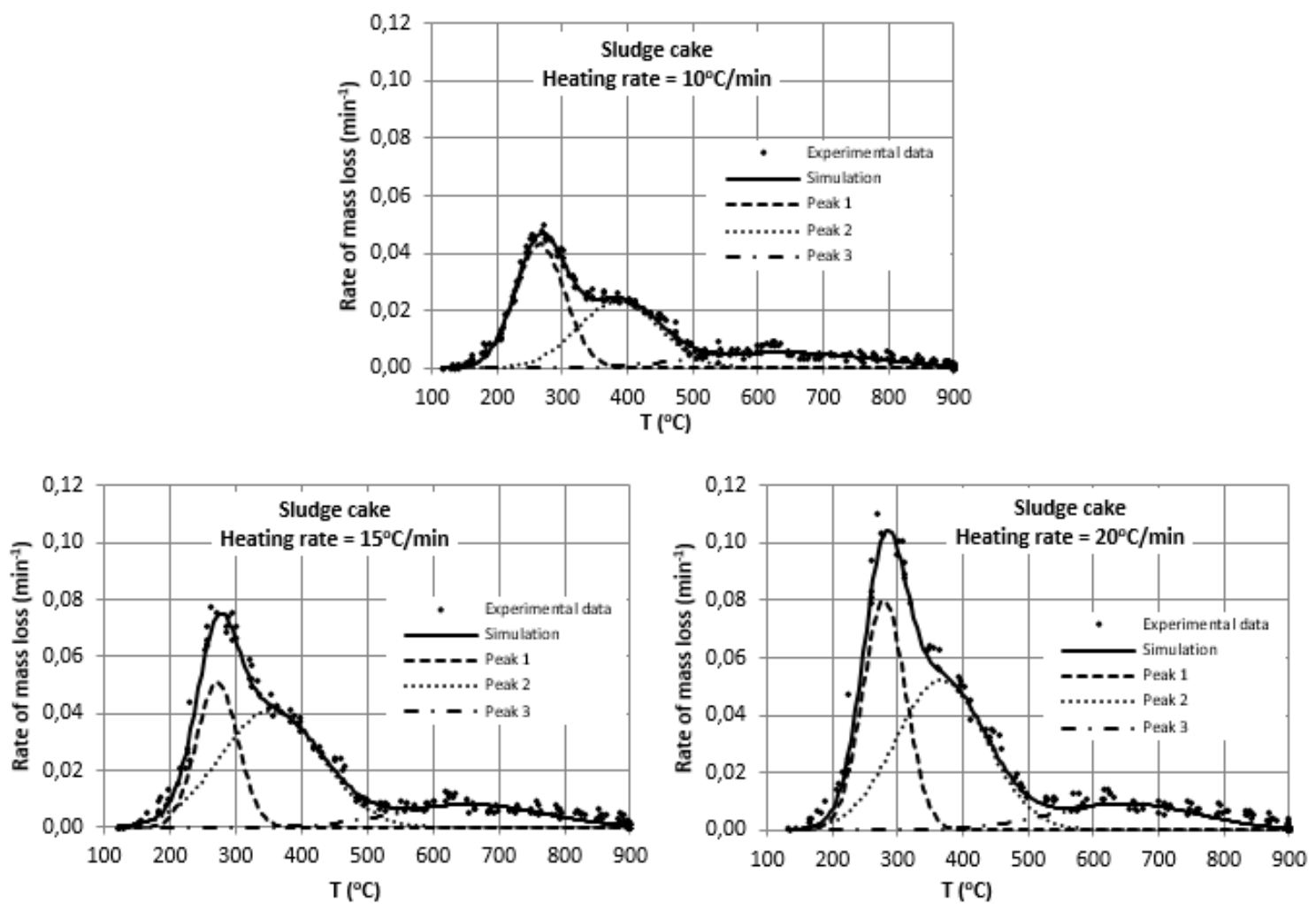

Figure 4. The gaussian peak fitting which separating the mass loss rate peaks were overlaping with several individual peaks for the pyrolysis of sludge with a heating rate of 10,15 , and $20^{\circ} \mathrm{C} / \mathrm{min}$ 

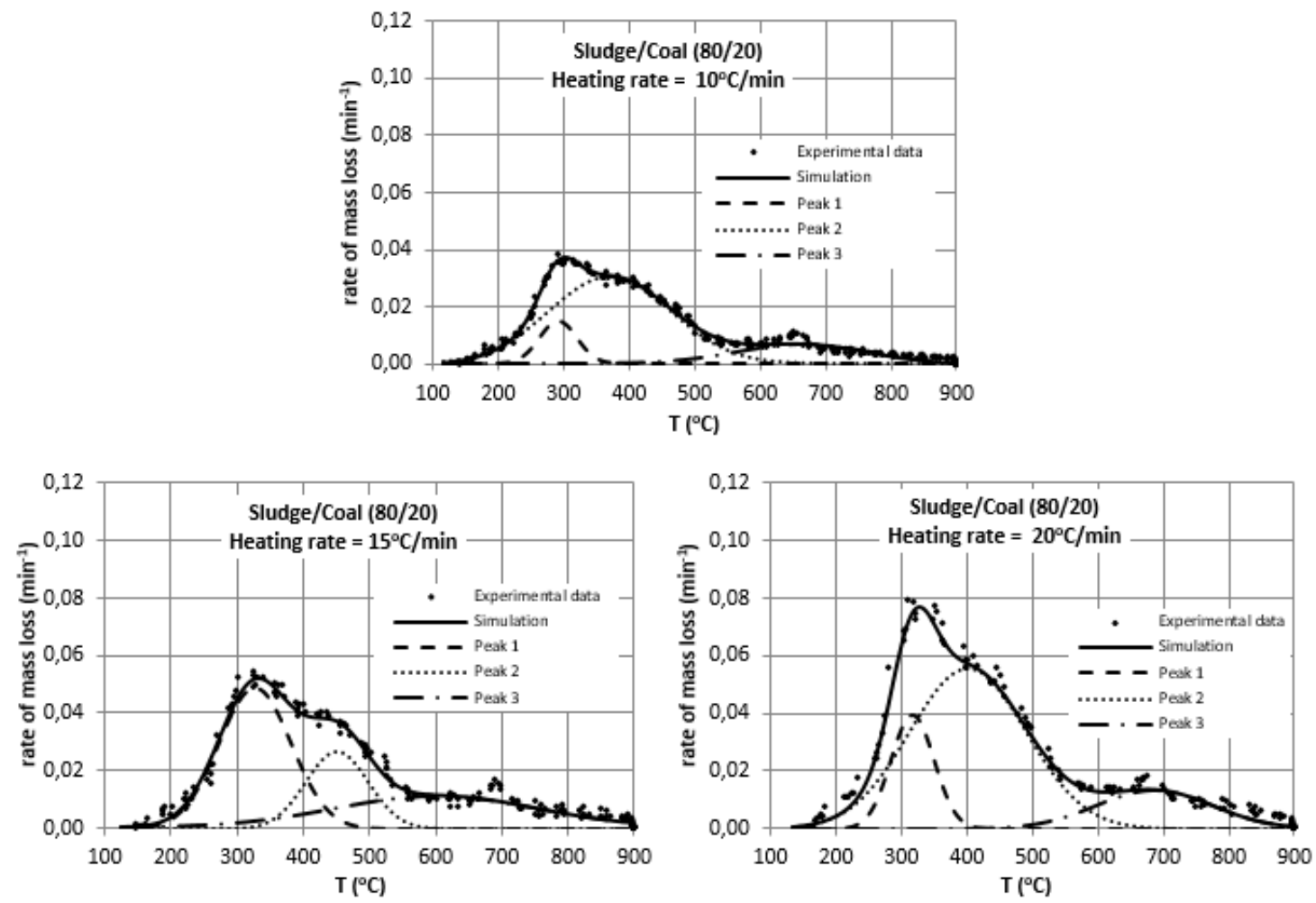

Figure 5. The gaussian peak fitting which separating the mass loss rate peaks were overlaping with several individual peaks for the pyrolysis of sludge/coal (80/20) with a heating rate of 10,15 , and $20^{\circ} \mathrm{C} / \mathrm{min}$
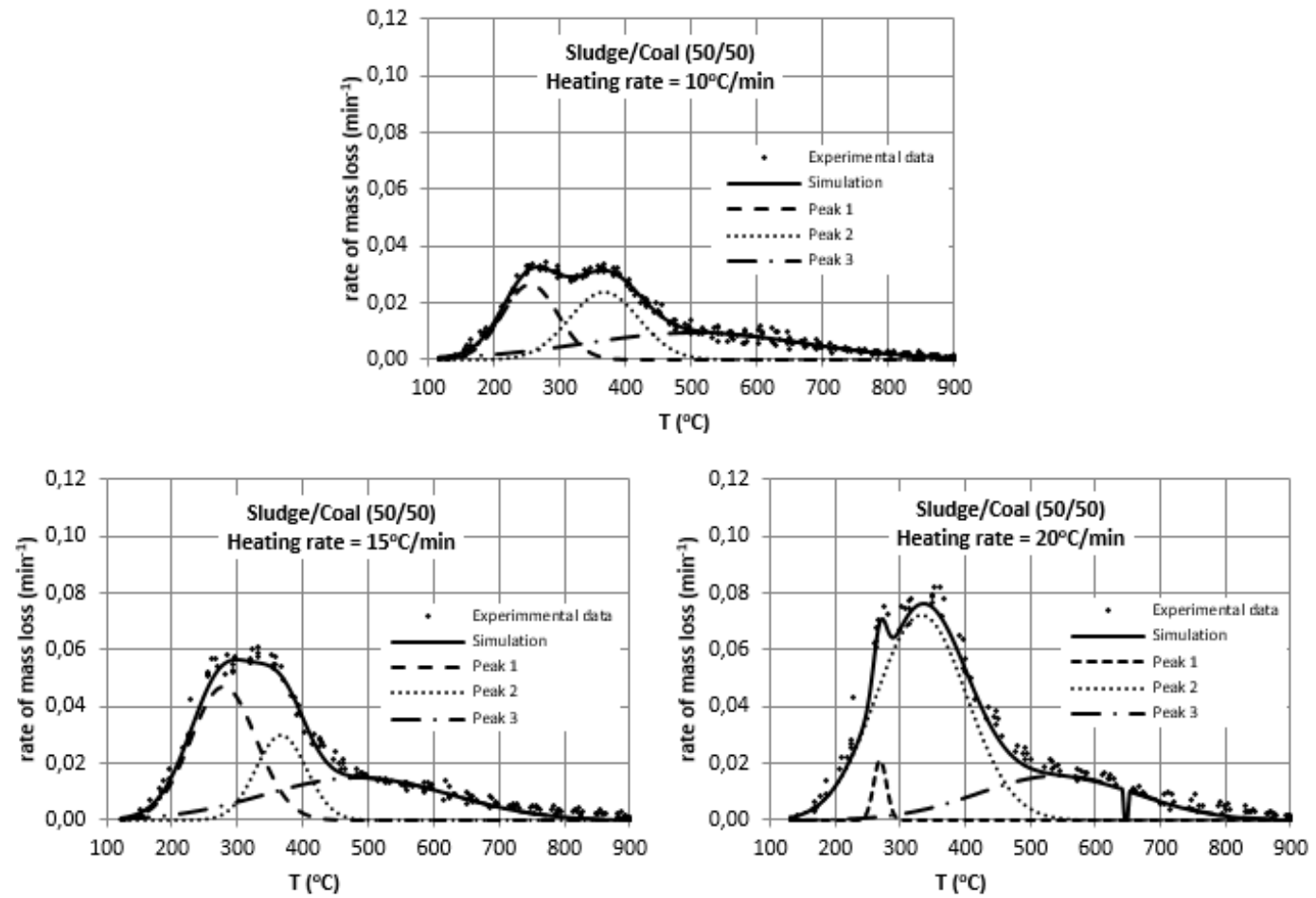

Figure 6. The gaussian peak fitting which separating the mass loss rate peaks were overlaping with several individual peaks for the pyrolysis of sludge/coal (50/50) with a heating rate of 10,15 , and $20^{\circ} \mathrm{C} / \mathrm{min}$ 

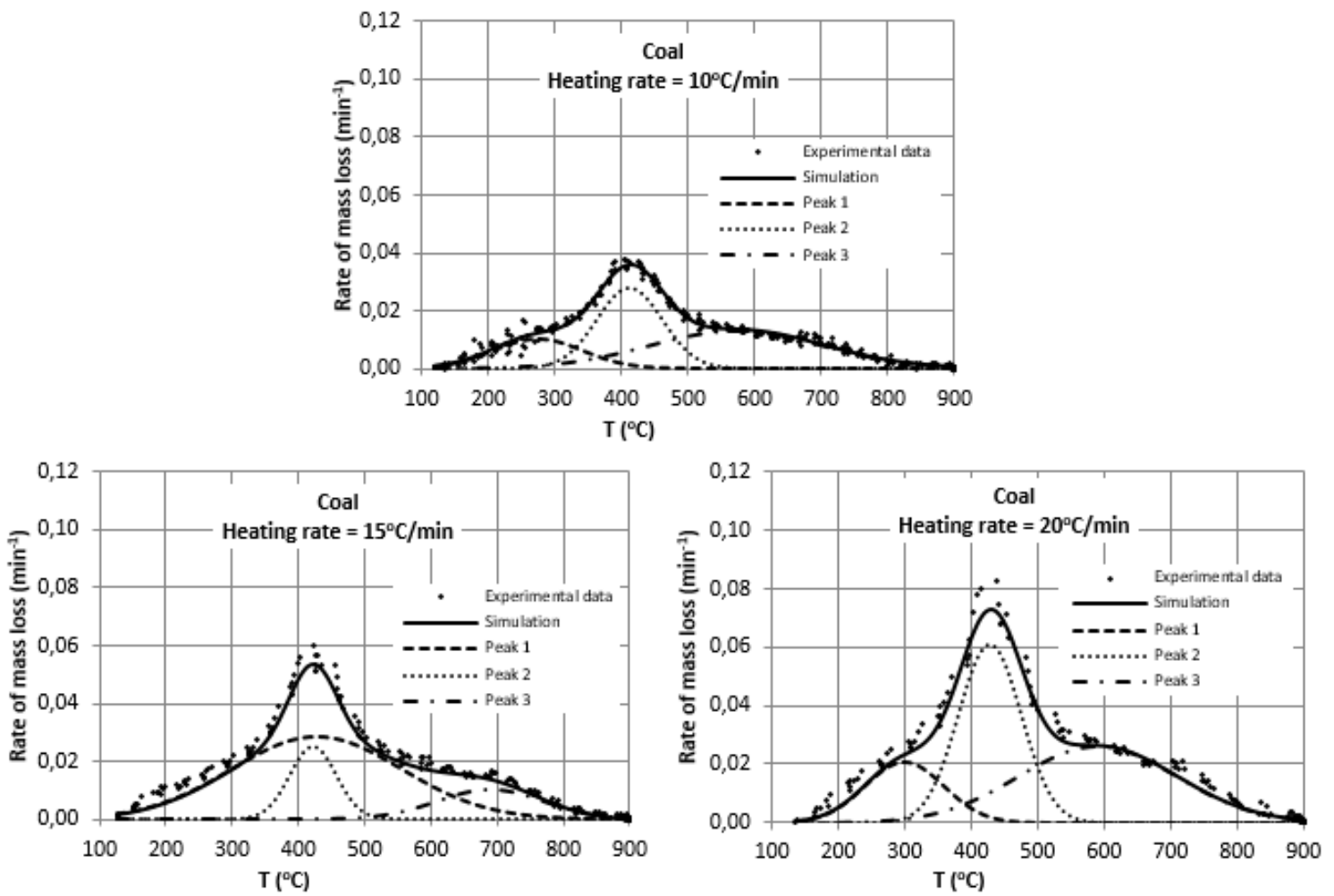

Figure 7. The gaussian peak fitting which separating the mass loss rate peaks were overlaping with several individual peaks for the pyrolysis of coal with a heating rate of 10,15 , and $20^{\circ} \mathrm{C} / \mathrm{min}$

\section{Pyrolysis Kinetics}

Based on the composition and the curve of mass loss rate, the gaussian fitting was resulting three peaks which indicate there were three reaction mechanisms of sludge-coal pyrolysis. Each peak representing the decomposition reaction of organic components in the blend of sludge-coal, i.e. hemicellulose, cellulose and lignin. Activated sludge microorganisms as a part of the organic component of sludge was also considered to be consisted on these compounds.

Generally, all experimental data can be approximated through pyrolysis model of three components, i.e. hemicellulose, cellulose, lignin. The pyrolysis rate values of these pseudo threecomponent should be describing the real rate of biomass pyrolysis. Peak 1 was likely to be occured due to the decomposition of hemicellulose and other highly volatile components at low temperatures $\left(220-315^{\circ} \mathrm{C}\right)$ and a peak at a temperature around $270^{\circ} \mathrm{C}$. Hemicellulose could be decomposed by dehidration at low temperatures $\left(<280^{\circ} \mathrm{C}\right)$, and could be depolymerization at higher temperatures. All studies showed that hemicellulose was the major component of wood which was mostly unstable, probably due to their lack of crystallinity (Yang et al., 2007). Sludge has approximately $4.40 \% \mathrm{w} / \mathrm{w}$ of hemicellulose content, which consequently degradation of hemicellulose at low temperature may produce high yield of char.

Peak 2 was associated with cellulose that occurs at the temperature range of $260-500^{\circ} \mathrm{C}$. Sludge was containing a total cellulose content for about $30.63 \% \mathrm{w} / \mathrm{w}$. Cellulose should be degraded at temperatures of $315-400^{\circ} \mathrm{C}$, with its decomposition peak rate at approximately around $350^{\circ} \mathrm{C}$ (Yang et al., 2007). Stefanidis et al. (2014) reported that cellulose was decomposed at a relatively narrow temperatures range between $280^{\circ} \mathrm{C}$ and $360^{\circ} \mathrm{C}$ with the fastest decomposition rate occured at $339^{\circ} \mathrm{C}$. The decomposition temperature range was highly well defined due to the a very homogeneous of cellulose crystalline structure with branchless crystalline structure of D-glucose units.

Peak 3 was associated with the decomposition of lignin and inorganic substances. Lignin is thermally more stable than cellulose and 
Table 2. Summary of temperature degradation and first order kinetic parameters of sludge pyrolysis and its blending with coal

\begin{tabular}{|c|c|c|c|c|c|c|c|}
\hline No. & $\begin{array}{l}\text { Heating rate, } \\
{ }^{\circ} \mathrm{C} / \mathrm{min}\end{array}$ & Peak & T range, ${ }^{\circ} \mathrm{C}$ & $\mathrm{T}$ peak, ${ }^{\circ} \mathrm{C}$ & $\begin{array}{c}\text { Relative } \\
\text { mass }\end{array}$ & $E a, \mathrm{~kJ} / \mathrm{mol}$ & $A, 1 / \mathrm{s}$ \\
\hline \multirow[t]{10}{*}{1.} & Sludge & & & & & & \\
\hline & & 1 & $200-350$ & 266 & 4.15 & 56.49 & 0.088 \\
\hline & 10 & 2 & $260-500$ & 386 & 3.63 & 54.96 & 0.320 \\
\hline & & 3 & $400-900$ & 642 & 1.74 & 19.45 & 0.083 \\
\hline & & 1 & $205-310$ & 272 & 3.98 & 89.21 & 0.218 \\
\hline & 15 & 2 & $180-50$ & 354 & 7.88 & 43.26 & 0.217 \\
\hline & & 3 & $400-900$ & 656 & 2.24 & 48.20 & 0.045 \\
\hline & & 1 & $200-330$ & 279 & 6.58 & 91.20 & 0.491 \\
\hline & 20 & 2 & $200-550$ & 367 & 9.02 & 44.80 & 0.118 \\
\hline & & 3 & $400-900$ & 648 & 2.52 & 47.15 & 0.235 \\
\hline \multirow[t]{10}{*}{2.} & Sludge/Coal $(80 / 20)$ & & & & & & \\
\hline & & 1 & $250-320$ & 292 & 1.06 & 92.37 & 0.395 \\
\hline & 10 & 2 & $180-600$ & 371 & 7.05 & 40.42 & 0.586 \\
\hline & & 3 & $450-900$ & 666 & 1.74 & 53.68 & 0.947 \\
\hline & & 1 & $200-450$ & 328 & 6.68 & 55.30 & 0.321 \\
\hline & 15 & 2 & $350-520$ & 452 & 3.13 & 94.86 & 0.201 \\
\hline & & 3 & $250-900$ & 600 & 4.12 & 29.27 & 0.114 \\
\hline & & 1 & $290-370$ & 316 & 3.25 & 54.28 & 0.421 \\
\hline & 20 & 2 & $200-600$ & 401 & 12.40 & 43.96 & 0.595 \\
\hline & & 3 & $500-900$ & 686 & 2.92 & 63.09 & 0.871 \\
\hline \multirow[t]{10}{*}{3.} & Sludge/Coal (50/50) & & & & & & \\
\hline & & 1 & $160-320$ & 256 & 2.76 & 59.32 & 0.107 \\
\hline & 10 & 2 & $250-450$ & 368 & 3.19 & 67.11 & 0.217 \\
\hline & & 3 & $160-900$ & 506 & 3.83 & 19.76 & 0.118 \\
\hline & & 1 & $160-380$ & 278 & 5.91 & 52.13 & 0.288 \\
\hline & 15 & 2 & $300-420$ & 367 & 2.90 & 83.00 & 0.251 \\
\hline & & 3 & $160-900$ & 484 & 5.36 & 21.51 & 0.116 \\
\hline & & 1 & $250-290$ & 269 & 0.52 & 25.91 & 0.385 \\
\hline & 20 & 2 & $200-480$ & 333 & 12.61 & 47.81 & 0.407 \\
\hline & & 3 & $250-900$ & 543 & 4.69 & 29.45 & 0.114 \\
\hline \multirow[t]{10}{*}{4.} & Coal & & & & & & \\
\hline & & 1 & $160-380$ & 274 & 1.76 & 29.45 & 0.866 \\
\hline & 10 & 2 & $300-500$ & 412 & 3.49 & 83.22 & 0.220 \\
\hline & & 3 & $200-900$ & 571 & 4.33 & 37.51 & 0.957 \\
\hline & & 1 & $160-750$ & 428 & 9.04 & 28.46 & 0.904 \\
\hline & 15 & 2 & $390-470$ & 422 & 2.20 & 87.71 & 0.573 \\
\hline & & 3 & 500-900 & 689 & 2.07 & 75.59 & 0.735 \\
\hline & & 1 & 180-380 & 299 & 3.03 & 41.33 & 0.668 \\
\hline & 20 & 2 & $320-520$ & 428 & 7.19 & 90.87 & 0.694 \\
\hline & & 3 & $300-900$ & 591 & 7.80 & 41.32 & 0.940 \\
\hline
\end{tabular}


hemicellulose, and produce more char and a higher fraction of aromatic compounds. The high residual lignin was associated with lignin structures, which has an amorphous structure and composed of a complex network of crosslinked aromatic molecules which difficult to decompose, and therefore has a high thermal stability. These properties lead lignin to be degraded slower and its mass loss occurred in a very wide temperature range of $160-900^{\circ} \mathrm{C}$ (Yang et al., 2007; Stefanidis et al., 2014). Sludge was containing lignin about $21.41 \% \mathrm{w} / \mathrm{w}$ and less fixed-carbon $(11.15 \% \mathrm{w} / \mathrm{w})$, thus the decomposition of sludge showed a weak peak at approximately around $640^{\circ} \mathrm{C}$.

Furthermore, the decomposition kinetics was also analyzed by first order reaction mechanism. Peak 1 had activation energy (E) in ranges of $28-93 \mathrm{~kJ} / \mathrm{mol}$. The activation energy of hemicellulose decomposition reactions reported in literature were in ranges of $82-156 \mathrm{~kJ} / \mathrm{mol}$ (Thipkhunthod et al., 2007). The peak 2 had activation energy (E) in ranges of 40-95 $\mathrm{kJ} / \mathrm{mol}$. The activation energy of cellulose decomposition reactions reported in literature were in ranges of $124-284 \mathrm{~kJ} / \mathrm{mol}$ (Thipkhunthod et al., 2007). The peak 3 had activation energy in ranges of $19-76 \mathrm{~kJ} / \mathrm{mol}$. The activation energy of lignin decomposition reactions were reported in literature in ranges of 19-65 kJ/mol (Thipkhunthod et al., 2007). The difference in the value of the activation energy was due to differences in the composition of the raw materials. In this study, the raw material used was blend of sludge and coal, while the literature used pure raw materials (hemicellulose, cellulose, and lignin).

\section{Conclusions}

The addition of coal to the blend of sludge has resulting in increased of time required to complete the pyrolysis process. This phenomenon indicated that volatile matter in the coal was more difficult to be degraded. The higher heating rate lead to the decrease of the char yield. The addition of coal into the blend of sludge may reduce the yield of char due to the higher sludge ash content on sludge compared to coal. The wide range of coal degradation temperature indicates that the coal may contains some components that have a wide range of temperature degradation, such as lignin. On the other hand, the phenomenon was also probably occured due to the fact that the coal devolatilization reactions involving more reaction than the devolatilization reactions of sludge. Thus it concluded the possibility that volatile matter in the coal were not easily degraded at low temperatures. Based on the composition and the curve of pyrolysis mass loss rate, there were threepeaks which indicated three mechanisms of sludge-coal pyrolysis reaction. Analysis of the decomposition kinetics with first order reaction describe three peaks, namely: peak 1 with activation energy in ranges of $28-93 \mathrm{~kJ} / \mathrm{mol}$ which was associated with decomposition of hemicellulose and other highly volatile components, peak 2 in ranges of $40-95 \mathrm{~kJ} / \mathrm{mol}$ which was associated with decomposition of cellulose, and peak 3 in ranges of $19-76 \mathrm{~kJ} / \mathrm{mol}$ which was associated with decomposition of lignin and inorganic substances.

\section{Acknowledgement}

This research was supported by LinneausPalme Students Exchange Program 2013. The authors acknowledge the support of Dr. Ronny Purwadi, Dr. Anita Pettersson and Kehinde Olubukola Oluoti.

\section{References}

Biagini, E., Lippi, F., Petarca, L. and Tognotti, L. (2002) 'Devolatilization rate of biomasses and coal-biomass blends: an experimental investigation', Fuel. Elsevier, 81(8), pp. 1041-1050. doi: 10.1016/S00162361(01)00204-6.

Chen, T., Li, L., Zhao, R. and Wu, J. (2017) 'Pyrolysis kinetic analysis of the three pseudocomponents of biomass-cellulose, hemicellulose and lignin', Journal of Thermal Analysis and Calorimetry. Springer Netherlands, 128(3), pp. 1825-1832. doi: 10.1007/s10973-016-6040-3.

Chen, X., Liu, L., Zhang, L., Zhao, Y., Zhang, Z., Xie, X., Qiu, P., Chen, G. and Pei, J. (2018) 'Thermogravimetric analysis and kinetics of the co-pyrolysis of coal blends with corn stalks', Thermochimica Acta. Elsevier, 659, pp. 59-65. doi: 10.1016/J.TCA.2017.11.005.

Coimbra, R. N., Paniagua, S., Escapa, C., Calvo, L. F. and Otero, M. (2015) 'Thermogravimetric analysis of the co-pyrolysis of a bituminous coal and pulp mill sludge', Journal of Thermal Analysis and Calorimetry. Springer Netherlands, 122(3), pp. 1385-1394. doi: 10.1007/s10973-015-4834-3. 
Fang, S., Yu, Z., Lin, Y., Hu, S., Liao, Y. and Ma, X. (2015) 'Thermogravimetric analysis of the co-pyrolysis of paper sludge and municipal solid waste', Energy Conversion and Management. Pergamon, 101, pp. 626-631. doi: 10.1016/J.ENCONMAN.2015.06.026.

Liu, G., Song, H. and Wu, J. (2015) 'Thermogravimetric study and kinetic analysis of dried industrial sludge pyrolysis', Waste Management. Pergamon, 41, pp. 128133. doi: 10.1016/J.WASMAN.2015.03.042.

Scott, G. M., Abubakr, S. and Smith, A. (1995) 'Sludge characteristics and disposal alternatives for the pulp and paper industry', International Environmental Conference, pp. 269-279. doi: 10.1017/ CBO9781107415324.004.

Scott, S. A., Dennis, J. S., Davidson, J. F. and Hayhurst, A. N. (2006) 'Thermogravimetric measurements of the kinetics of pyrolysis of dried sewage sludge', Fuel. Elsevier, 85(9), pp. 1248-1253. doi: 10.1016/J. FUEL.2005.11.003.

Stefanidis, S. D., Kalogiannis, K. G., Iliopoulou, E. F., Michailof, C. M., Pilavachi, P. A. and Lappas, A. A. (2014) 'A study of lignocellulosic biomass pyrolysis via the pyrolysis of cellulose, hemicellulose and lignin', Journal of Analytical and Applied Pyrolysis. Elsevier, 105, pp. 143-150. doi: 10.1016/J.JAAP.2013.10.013.

Thipkhunthod, P., Meeyoo, V., Rangsunvigit, P. and Rirksomboon, T. (2007) 'Describing sewage sludge pyrolysis kinetics by a combination of biomass fractions decomposition', Journal of Analytical and Applied Pyrolysis. Elsevier, 79(1-2), pp. 7885. doi: 10.1016/J.JAAP.2006.10.005.
Wang, X., Deng, S., Tan, H., Adeosun, A., Vujanović, M., Yang, F. and Duić, N. (2016) 'Synergetic effect of sewage sludge and biomass co-pyrolysis: A combined study in thermogravimetric analyzer and a fixed bed reactor', Energy Conversion and Management. Pergamon, 118, pp. 399-405. doi: 10.1016/J.ENCONMAN.2016.04.014.

Werther, J. and Ogada, T. (1999) 'Sewage sludge combustion', Progress in Energy and Combustion Science. Pergamon, 25(1), pp. 55-116. doi: 10.1016/S03601285(98)00020-3.

Xiao, P., Xu, L., Wang, X. and Chang, Z. (2015) 'Co-pyrolysis characteristics of coal and sludge blends using thermogravimetric analysis', Environmental Progress \& Sustainable Energy. John Wiley \& Sons, Ltd, 34(6), pp. 1780-1789. doi: 10.1002/ ep. 12154 .

Yang, H., Yan, R., Chen, H., Lee, D. H. and Zheng, C. (2007) 'Characteristics of hemicellulose, cellulose and lignin pyrolysis', Fuel. Elsevier, 86(12-13), pp. 1781-1788. doi: 10.1016/J.FUEL.2006.12.013.

Yang, X. and Jiang, Z. (2009) 'Kinetic studies of overlapping pyrolysis reactions in industrial waste activated sludge', Bioresource Technology. Elsevier, 100(14), pp. 3663-3668. doi: 10.1016/J. BIORTECH.2009.03.002.

Zhou, H., Long, Y., Meng, A., Chen, S., Li, Q. and Zhang, Y. (2015) 'A novel method for kinetics analysis of pyrolysis of hemicellulose, cellulose, and lignin in TGA and macro-TGA', RSC Advances. Royal Society of Chemistry, 5(34), pp. 2650926516. doi: 10.1039/C5RA02715B. 